\title{
O ESTADO DE DIREITO E $O$ DIREITO DE AÇÃO (A EXTENSÃO dO SEU EXERCíCIO (*)
}

\author{
EGAS DIRCEU MONIZ DE ARAGÃO(**)
}

1. É evidente a conotação entre "Estado de Direito" e "direito de ação". Manifesta, portanto, a exatidão do raciocínio que orientou a elaboração da agenda da Conferência, ao incluir o tema entre os que devem ser debatidos.

Caso é, contudo, de fixar desde logo algumas delimitações, aptas a facilitaram a compreensão das idéias a serem desenvolvidas.

2. Em primeiro lugar, não é possível ultrapassar-lhe as proporções, pois tratar desse assunto sob todos os aspectos implicaria em passar em revista o próprio Direito Processual. Bem percebendo essa dificuldade, os organizadores do temário reduziram-no à extensão do seu exercício.

Em segundo lugar, parece acertado excluir o aspecto processual penal, por diversos motivos: a) falta ao autor conhecimento, autoridade e experiência para viagens de longo curso; o bom senso the recomenda manter-se na cabotagem do processo civil; b) no plano penal, afora a garantia do habeas corpus, que, para o objetivo visado, será suficientemente abordada, o mais interessante não é a "extensão de seu exercício", (do ângulo que, em seguida, irá ser analisado), pois isso incumbe ao Estado, ressalvadas poucas exceções (as impropriamente denominadas ações privadas), mas outro aspecto dessa realidade: 0 direito de defesa; c) não carece o Estado de que se the assegure o direito de ação no âmbito penal, pois não costuma ele encabular-se de exercê-lo, até mesmo de exceder-se nisso; conviria examinar, isto sim, a garantia de que o indivíduo deve desfrutar, de sofrer a ação penal em juízo, sujeita ao processo e às suas formas, que lhe constituem garantia evidente, mas que deve ser matéria para outra oportunidade.

Em terceiro lugar, o trabalho versará sobre duas dentre as, atual-

(*) Tese apresentada à VII Conferência Nacional da Ordem dos Advogados do Brasil.

${ }^{(*)}$ Professor Catedrático de Direito Processual Civil da U.F.Pr.. 
mente, chamadas condições da ação (Código de Processo Civil, artigo 267, inc. VI): a possibilidade jurídica do pedido e a legitimidade ativa para agir, investigando-se, assim, a extensão do exercício do direito de ação do ângulo do indivíduo, para quem constitui garantia constitucional. Ficará de lado a outra ccndição, o interesse de agir, sobre a qual não recai suspeita de ensejar dificuldades a esse título.

Em quarto lugar, tendo em vista a sua também evidente importância, será tratado o crucial problema da lentidão processual, pois, como dizia Bacon, se a injustiça da sentença a faz azeda, a demora torna-a amarga.

Por fim, em quinto lugar, serão abordados alguns aspectos colaterais, mas integrados no enunciado proposto, quais sejam: a efetividade do resultado do exercício do direito de ação, no que concerne à indispensabilidade da atuação de advogados e juízes, sem os quais tuda cairia no vazio. Disso resulta a conveniência de passar uma vista d'olhos pela assistência judiciária e a preparação intelectual desses profissionais.

3. Durante cerca de dois milênios prevaleceu a conceituação romana do direito de ação, tido como imanente ao próprio direito material feito valer através do processo. São denominadas imanentistas, ou civilistas (pelo preponderante papel do Direito Civil), as teorias a esse respeito, desenvolvidas à sombra de conhecida definição exposta pelo jurisconsulto Celso: actio autem nihil aliud est, quam ius persequendi iudicio quod sibi debetur (a ação nada mais é do que o direito de alguém de perseguir em juízo o que lhe é devido) ('Digesto', 44, 7,51).

Célebre polêmica travada entre Windscheid e Muther, ao iniciarse a segunda metade do século XIX (1), serviu para iluminar o assunto, que passou a ser enxergado por outros ângulos, e desencadear fervilhante revisão do conceito romano, o qual cedeu lugar a novas doutrinas, conhecidas como autonomistas, que, desvinculando-o do direito material, atribuiram ao direito de ação vida própria.

Essa polêmica teve duplo merecimento, pois, além de versar sobre o ccnceito da ação, também agitou outro tema de grande relevo: sua pertinência ao ramo público do Direito, por caber ao Estado prestar a tutela jurisdicional, direito este exercido com exclusividade, mas que constitui um dever estatal para com os jurisdicionados, aos quais não the será lícito sonegar o correspondente direito de exigir a prestação desse encargo. A ação passou a ser incluída entre os chamados direitos públicos subjetivos.

1 V. 'Polêmica Sobre la "Actio", trad. TOMAS A. BASSHAF, Buenos Aires, 1974. 
Em torno do conceito de ação propriamente dito, surgiram, então, diversas teorias, que podem ser agrupadas, grosso modo, em duas grandes correntes: a dos juristas que vinculam o direito de ação ao resultado proporcionado pela sentença (teoria do direito concreto de agir: não tem ação quem não tem direito), e a dos que o desvinculam do resultado final (teoria do direito abstrato de agir: pode ter ação quem pode não ter direito). Dentre aquelas sobressai a de Chiovenda, que qualificava a ação como mero poder jurídico, incluído entre os chamados direitos prestativos, merecendo referência pelo muito que influiu no pensamento jurídico moderno, conquanto tenha tido pouquíssimos seguidores. $\left({ }^{2}\right)$

4. O Código de Processo Civil em vigor (e, de certo modo, o anterior já chegara a resultado idêntico), adota, dentre todos, o conceito exposto por Liebman, fruto de larga meditação, cujo ápice foi atingido com a aula proferida a 24 de novembro de 1949, na Universidade de Turim. ( $\left.{ }^{3}\right)$

5. Conforme expõe Liebman, a ação é direito - (considera ele irrelevante o debate em torno de saber se se trata de "direito" ou de "poder jurídico") - abstrato, isto é, para assegurar a a'guém o seu exercícic deve-se abstrair de ter esse alguém, ou não, direito (material), ou seja, de ter, ou não, razão quando ingressa em juízo pois somente a sentença definirá esse aspecto.

Mas não é um direito incondicionado de mero acesso aos tribunais, que possa ser exercido por qualquer um, sem quaisquer limitações; ao contrário, para que seja possível exercê-lo deverá o interessado preencher três requisitos, as chamadas condições da ação, a saber: possibilidade jurídica do pedido, legitimidade para a causa e interesse processual.

Segue-se que não será cạbível exercer o direito de ação (ocorrerá a chamada carência da ação), por quem não preencher esses três requisitos.

6. Sem divergir de noção ccmo essa, Eduardo Couture, que tinha aguda visão das conotações constitucionais do Direito Processual, trouxe ao debate outro detalhe, só mais tarde valorizado por juristas da Europa continental: a implicação ccnstitucional do direito de ação, motivo de, nele, ter destacado o papel que o indivíduo de-

2 V. "La Acción en el Sistema de los Derechos", in "Ensayos de Derecho Procesal Civil, trad. SANTIAGO SENTÍS MELENDO, Buenos Aires, 1949, 1/3.

3 "L'Azione Nella Teoria del Processo Civile", in"Problemi del Processo Civile", Nápoles, 1962, pág. 22. 
sempenha, aproximando-o, por isso, do direito de petição, o que the dá relevo ímpar no estado de direito. $\left({ }^{4}\right)$

Essa tese, que logo chamou a atenção do Ministro Castro Nunes, grande publicista brasileiro, pois "supera as idéias clássicas no plano processual ", $\left({ }^{5}\right)$, começa a ser festejada na ltália, como se observa no livro de Luigi Paolo Comoglio, que a considera "sugestiva". $\left.{ }^{6}\right)$

7. Nos países anglo-saxônicos, as implicações constitucionais do direito de ação cedo vieram à tona. Foi o que sucedeu na Inglaterra e nos Estados Unidos da América do Norte com a cláusula due process of law, que remonta, com essa designação, ao Século XIV e figura nas Emendas de $n .^{\circ} \mathrm{s} V$ e XIV à Constituição dos Estados Unidos.

Pontes de Miranda refere-se à Constituição de 1819 de Würtenberg, cujo § 95 é exemplo de texto protetor da "pretensão à tutela jurídica". ( (7)

A Declaração Universal dos Direitos do Homem, aprovada pela Assembléia Geral das Nações Unidas a 10 de dezembro de 1948, contemplcu o direito de ação nestes termos: toda pessoa tem direito, em condições de plena igualdade, de ser ouvida publicamente e com justiça por tribunal independente e imparcial, para a determinação de seus direitos e obrigações ou para o exame de qualquer acusação contra ela em matéria penal.

8. No Brasil, contudo, foi apenas através do $\S 4 .^{\circ}$ do artigo 141 da Constituição de 18 de setembro de 1946 que a matéria atingiu relevo constitucional, embora haja quem tenha pretendido identificála no artigo 179, inciso XII, da Constituição do Império. $\left.{ }^{8}\right)$

Conquanto na Assembléia Constituinte surgissem opositores à sua introdução no texto (Hermes Lima, por exemplo), fundados em que seria dedutível dos demais princípios constitucionais e a esse

4 V. "Fundamentos do Direito Processual Civil", trad. RUBENS GOMES DE SOUZA, São Paulo, 1946, págs. 41 e segs.; "Las Garantias Constitucionales del Processo Civil", in "Estudios do Derecho Procesal Civil", Buenos Aires, 1948, 1/29. Embora não seja possível dizer que haja chegado a conclusões similares às de COUTURE, é interessante notar que a Suprema Corte do Japão, a 6 de julho de 1960, analisando o texto constitucional que assegura o direito de acesso aos tribunais, afirmcu que "a Constituição reconhece o Direito de Petição de Julgamento como um direito humano fundamental" (YASUHEI TANIGUCHI, in "Fundamental Guarantees of the Parties in Civil Litigation", coletânea sob direção de MAURO CAPPELLETTI e DENIS TALLON, Milão, 1973, pág. 578).

5 V. “Do Mandado de Segurança", 2.a ed., (a 1.a é de 1937-, Rio, 1948, n.0 22, pág. 51, nota n. 020 .

6 "La Garanzia Constituzionale Dell'Azione ed il Processo Civile", Pádua, 1970, pág. 75 e nota n.0 110.

7 "Comentários à Constituição de 1946", 3. ed., Rio, 1960, IV/418.

8 ALCINO PINTO FALCÃO, "Constituição Anotada", Rio, 1957, II/67.

pe

ria

$\mathrm{Ke}$

de

na

qu

ex

$\mathrm{Pe}$

tel

qu

fo

te

pi

pa

ar

aç

tá

qi

$d \epsilon$

$\mathrm{ci} i$

se

a

é

ra

$\mathrm{cr}$

di

tr

cr

di

se

ni

$-$

9

10

11 
pensamento hajam aderido alguns dentre seus intérpretes $\left({ }^{9}\right)$, a maioria preferiu conservá-la na declaração de direitos, cabendo a Prado Kelly, em debate com Agamenon Magalhães, a primazia da emenda de redação cujos dizeres, de então para cá, vêm sendo reproduzidos nas cartas subseqüentes. $\left({ }^{10}\right)$

Pontes de Miranda, em primeiro lugar $\left({ }^{1}\right)$, e José Frederico Marques posteriormente $\left({ }^{12}\right)$, nele identificaram expressa proteção ao exercício do direito de ação, assunto retomado, recentemente por Ada Pellegrini Grinover ${ }^{(13)}$. Juízes e tribunais, porém, parecem não the ter dado maior importância, como lamenta esta última $\left({ }^{14}\right)$, talvez porque - a observação é de Pontes - sofressem os efeitos de terem formado sua mentalidade em períodos ditatoriais $\left({ }^{15}\right)$, ou de a estes terem-na amoldado. O mesimo não se poderia dizer dos que, na República velha, esforçaram-se por dilatar o âmbito do habeas corpus para melhor lutelar direitos individuais atrav-s do direito de ação.

9. Apesar de referir-se à lei, o disposto no $\S 4 .^{\circ}$ do, hoje, artigo 153 da Constituição põe em relevo a garantia do direito de ação não apenas em face do Poder Público, que é o primeiro destinatário da norma, mas de todos quantos, de qualquer modo, possam querer impedi-lo. É que se a lei não pode, nenhum ato ou autoridade de menor hierarquia poderá "excluir da apreciação do Poder Judiciário qualquer lesão de direito individual". Ademais, a proteção não se destina a assgeurar o exercício do direito de ação somente quando a pretensão é endereçada contra o Estado, mas também quando o é contra qualquer pessoa, jurídica ou física.

Quanto a esse aspecto seria adequado investigar a validade perante a norma constitucional do comportamento das instituições de crédito, a começar pelas oficiais, que exigem de seus clientes certidões negativas dos distribuidores de processos cíveis, exercendo estranha pressão, que leva a concluir-se só deverem ter livre acesso ao crédito pessoas que não litigam. Em muitas ocasiões poderá suceder de o interessado na operação financeira ver-se compelido a sacrificar seu direito, para não ficar comprometido diante dos banqueiros, ou não encontrar fechadas as portas de seus estabelecimentos.

9 PINTO FALCÃO, ob. e loc. cit.; EDUARDO ESPÍNOLA, "Constituiçāo dos Estados Unidos do Brasil", Rio, 1952, II/552-553.

10 V. JOSÉ DUARTE, "A Constituição Brasileira de 1946", Rio, 1947, III/16-21.

11 "Comentários à Constituição", ob. cit., IV/418.

12 "O Artigo 141, § 4.०, da Constituição Federal", in "Revista de Direito Processual Civil" São Paulo, 1960, 11/13.

13 "A Garantia Constitucional do Direito de Aģão e sua Relevância no Processo Civil", São Paulo, 1972.

14 "Os Princípios Constitucionais e Processo Civil", São Paulo, 1975, pág. 146.

15 "Comentários à Constituição", ob. cit., IV/415-416 
Deve considerar-se excluída pela norma constitucional até mesmo a possibilidade de as partes avençarem a inacionabilidade de qualquer pretensão $\left({ }^{16}\right)$, pois as garantias individuais devem ser tidas ccımo direitos indisponíveis sob esse aspecto, conquanto lhes seja lícito instituirem juízo arbitral, cujo epílogo se desenrola perante o próprio Poder Judiciário (Código de Processo Civil, artigos 1.098/ 1.102), acatada a norma constitucional, que, por outro lado, não inibe a autocomposição ou mesmo a inércia da parte.

10. Visto que o exercício do direito de ação não é incondicionado, convém examinar o reflexo dos dois apontados requisitos sobre a extensão de seu exercício, considerada a regra constitucional.

Ao falar de possibilidade jurídica, Chiovenda identificava-a com "a existência de uma vontade de lei que assegure a alguém um bem obrigando o réu a uma prestação" $\left({ }^{17}\right)$, assim autorizando o interessado a formular a pretensão. Em outro livro, esclareceu que, por inexistir na Itália preceito igual ao do artigo $1 .^{\circ}$ do Código Civil Suíço $\left.{ }^{18}\right)$, a pré-existência da vontade concreta da lei, isto é, da regra legal autorizadora, é essencial ao exercício do direito de ação; sem ela não há possibilidade jurídica. (19) Sua idéia casaria com a interpretação, ao pé-da-'etra, do disposto no $\S 22^{\circ}$ do artigo 153 da Constituição ("ninguém será obrigado a fazer ou deixar de fazer alguma coisa senão em virtude da $\left(e^{\prime \prime}\right)$. $\left({ }^{20}\right)$

11. Liebman conservou a idéia chiovendiana, quanto ao núcleo, definindo a possibilidade jurídica como "a admissibilidade em abstrato do pronunciamento pretendido, segundo as normas vigentes no ordenamento jurídico nacional“". (21) Mas, simultaneamente dá a entender que tal condição deverá ser confrontada com o ordenamento jurídico positivo não para, nele, localizar a norma permissiva do exercício do direito de ação, mas, isto sim, para examinar se nenhum texto legal o exclui no caso concreto, como parece decorrer destas palavras de crítica à opinião de Redentti: "o autor é livre de configurar sua demanda como melhor se aprouver, desde que o pronunciamento pretendido não seja, em abstrato inadmissível (como seria uma

16 O assunto é bastante controvertido na Alemanha, como observa NICOLO TROCKER ("Processo Civile e Costituzicnale", Milão, 1974, pág. 184, nota n.0 42), citando vários autores a respeito.

17 "Instituições de Direito Processual Civil", trad. J. G. MENEGALE, 2.a ed. bras., São Paulo, 1965, § 3.0, n.० 19, 1/66.

18 "Na ausência de texto legal aplicável, o juiz decidirá segundo o direito costumeiro e, na ausência deste, segundo as regras que estabeleceria se tivesse de legislar".

19 "Principii di Diritło Processuale Civile", 4.a ed., Nápoles, 1928. págs. 74/75.

20 V. JOAQUIM CANUTO MENDES DE ALMEIDA, "A Liberdade Jurídica no Direito no Processo", excerto do livro "Estudos Jurídicos em Homenagem a Vicente Ráo", São Pau'o, 1976.

21 "Problemi", cb cit, pág 46 
sentença de divórcio na Itália, ou a prisão do devedor que nãc paga)". ${ }^{(22)}$

12. Já bem antes, em trabalho escrito no Brasil e tendo em vista o ordenamento jurídico nacional, acrescentara ao sovado exemplo da proibição do divórcio e do descabimento, à época, de mandado de segurança contra ato do Presidente da República, dos Ministros de Estado, dos Governadores e dos Interventores, inscrita no artigo 319, caput, do Código de Processo Civil de $1939\left({ }^{23}\right)$

Regras como a do artigo 319 do Código velho desapareceram com o advento da Consitiuição de 1946, mas reapareceram a partir de 1964, já agora subtraindo à apreciação do Poder Judiciário, por motivos meramente polííicos, inúmeras lesões de direito individual, seja com a proibição de questionar sobre atos praticados pelo Presidente da República, e mesmo por Governadores, à sombra dos chamados "Atos Institucionais", seja suprimindo o cabimento do habeascorpus quando o indivíduo é apenas suspeito de haver cometido certos delitos.

Em casos tais o direito de ação não pode ser exercido, por impossibilidade jurídica do pedido.

13. Afora essas, outras proibições padem ser apontadas, que resultam de motivos jurídicos. É o que se dá com o descabimento do habeas corpus "nos casos de punição disciplinar" (Código de Processo Penal, artigo 647), ou, por iguais razões, do mandado de segurança, que não é viável contra "ato de que caiba recurso administrativo com efeito suspensivo, independente de caução", ou contra "despacho ou decisão judicial, quando haja recurso" - (tem-se entendido que a proibição somente atua no caso de ter ele efeito suspensivo, pois, do contrário, poderia causar dano irreparável) -, "previsto nas leis processuais ou possa ser modificado por via de correção", e bem assim contra "ato disciplinar, salvo quando praticado por autoridade incompetente ou com inobservância de formalidade essencial" (Lei n. ${ }^{\circ}$ 1.533, de 31 de dezembro de 1951, artigo $5 .^{\circ}$ ).

Ainda é possível indicar a proibição de o Poder Judiciário intervir no exame do mérito do ało administrativo ou de questões mera-

22 "Problemi'ı, ob. cit., pág. 37. Parece convergir para esse mesmo resultado o pronunciamento da Corte Constitucional alemã, indicado por TROCKER: "Como norma imediatamente aplicável, ○ art. 19, § 4.0, assegura uma "possibilidade de ação" (Klagemoglichkeit) mesmo quando a lei ordinária não a prevê expressamente; vede a sentença n.० 28 do Bundesverfassungsgericht exarada a 17 de dezembro de 1969 e publicada in Entscheidungen cit., vol. 27, págs. 297 e segs., e 308" ("Processo Civile e Costituzione", ob. cit., pág. 163, nota n.० 5).

23 "O Despacho Saneador e o Julgamento do Mérito", n.0 11, in "Revista Forense", 104/216, ou "Estudos Sobre o Processo Civil Brasileiro", 2.a ed., São aPulo, 1976. pág. 97. 
mente políticas (assuntos cuja análise ultrapassa os limites deste estudo), pois isso infringirá o princípio constitucional da separação e independência dos poderes. Em tais casos, fica afastado o direito de ação, mas isso somente acontece se o próprio Poder Judiciário qualificar a questão como política ou julgar que a revisão judicial pretendida corresponde a incursão sobre o mérito do ato administrativo. ${ }^{24}$ )

14. Não exclui a possibilidade jurídica do pedido, pcis apenas the cria um pré-requisito, a exigência, a que fica subordinado o exercício de certas pretensões, de antes ser exaurida a via administrativa, desde que, é natural, com isso não se torne inalcançável a solução jurisdicional. Assim já entendia o Supremo Tribunal Federal $\left({ }^{25}\right)$, ao tempo da Constituição de 1946, com relação ao dever dos servidores públicos, civis e militares, de primeiro esgotarem os recursos admin'strativos para, depois, ingressarem em juízo. Também a Lei n. ${ }^{\circ}$ 1.533 , de 1951, que disciplina o mandado de segurança, parece orientada nesse rumo, em vista de facultar o seu exercício somente quando o recurso administrativo não tenha efeito suspensivo ou dependa da prestação de caução (artigo $5^{\circ}$ ).

(E possível que esse princípio haja inspirado ao Supremo Tribunal Federal a deliberação de, abandonando tendência liberal até então predominante em sua jurisprudncia, excluir a admissibilidade da impetração do habear corpus criginário em lugar do recurso contra sua denegação em tribunais inferiores, o que implica em exigir a exaustão normal da via judiciária).

Essa afirmativa conta com o apoio, dentre outros, de dois juristas italianos ultimamente dedicados ao exame científico das garantias constitucionais do processo civil: COMOGLIO $\left({ }^{26}\right)$ e TROCKER $\left({ }^{27}\right)$, os quais apontam julgados das Cortes Constitucionais alemã e italiana, coincidentes com a tese da exaustão da via administrativa, adotada pelo Supremo Tribunal Federal.

Por isso, a oração que passou a figurar no $\S 4 .^{\circ}$ do artigo 153 da Constituição $\left({ }^{28}\right)$, tendente a esse fim, parece desnecessária; mes-

24 Tanto na Inglaterra, quanto no Canadá e nos Estados Unidos da América do Norte, o controle jurisdicional dos atos administrativos é sujeito a limitações, pois, como escreve o inglês J.A. JOLOWICZ, a tarefa governamental "tornar-se-ia quase impossível se todas as decisões tomadas fossem suscetíveis de controle perante os tribunais" ("Fundamental Guarantees", cb. cit., pág. 151). V., no mesmo livro, as opiniões coincidentes do canadense GARRY D. WATSON e do norte-americano HANS SMIT, às pags. 218 e 422.

25 "Revisła Forense", 144/164; "Revista de Direito Administrativo", 38/66; "Revisła Trimestral de Jurisprudência", 43/696.

26 "La aGranzia", ob. cit., págs. 187/188 e 193.

27 "Processo Civile e Costifuzione", ob. cit., págs. 228, 235 e246. V. também MAURO CAPPELLETTI e VINCENZO VIGORITI, "Fundamental Guarantees", ob. cit., pág. 540.

28 "O ingresso em juízo poderá ser condicionado a que se exauram previamente as vias administrativas, desde que não exigida garantia de instância, nem ultrapassado o prazo de cento e oitenta dias para a decisão do pedido".

m in ir. re 
mo prestando fiel acatamento à tese de a lei não conter palavras inúteis, o máximo a que se pode chegar é à afirmativa de que sua inserção no texto resulta de haver preponderado a opinião da corrente que reputa indevida tal restrição, a qual tem adeptos tanto no Brasil quanto na Itália e na Alemanha.

Válida e útil, no entanto, é a fixação de um prazo e a liberação do ingresso em juízo, após seu término, mesmo que a via administrativa ainda esteja em curso.

15. No que concerne à legitimidade para propor a ação, prepondera na atualidade brasileira a opinião de Liebman, que assim a conceitua: "pertinência da ação àqquele que a propõe". ${ }^{(29)}$

Nesse conceito nota-se aparente círculo vicioso: tem legitimidade para propor a ação aquele a quem esta pertine, a qual por sua vez pertine àquele que pode propô-la e, por isso, é considerado parte legítima. Mas o autor remete ao artigo 81 do Código de Processo Civil italiano $\left({ }^{30}\right)$, com o que facilita a compreensão de seu pensamento sob dois ângulos distintos: um, porque esta norma regula a substituição procesual; outro porque fala em direito. A remissão denota que Liebman não só considera a legitimidade apenas do ponto-de-vista de quem age em benefício próprio, como toma o vocábulo ação como sinônimo de pretensão (a actio romana) e isso esclarece seu pensamento: pertinência da pretensão (actio) àquele que propõe a ação (em seu próprio benefício). Esta também era a lição de Chiovenda: "a identidade da pessoa do autor com a pessoa favorecida pela lei" $\left({ }^{31}\right)$, que, ao fim e ao cabo retrata o ensinamento de Celso: ius... persequendi... sibi debetur.

16. Numa visão constitucional do direito de ação, esse conceito, embora seja o mais aceito e respeitado parece não ser suficiente, por externar idéia um tanto privatística do 'Direito Processual, reduzida a ação a direito exercido em vista de litígio entre duas pessoas. Para que a norma inscrita no artigo $153, \S 4 .^{\circ}$, da Constituição preencha todas as suas finalidades e alcance todo o seu objetivo, conviria atribuir maior extensão ao conceito de legitimidade para propor a ação.

Essa evidente preocupaçăo levou o legislador, em alguns casos, a alargar a noção de legitimidade muito além de tão acanhados limites, como sucede relativamente ao habeas corpus (Código de Processo Penal, artigo 654), ou à ação popular (Lei n. ${ }^{\circ} 4.717$, de 29 de junho

29 "Problemi", ob. cit., pág. 46.

30 "Fora dos casos expressamente previstos em lei, ninguém pode fazer valer no processo, em nome próprio, um direito alheio".

31 "Instituiģöes", ob. cit.. 1/66. 
de 1965, artigo $1 .^{\circ}$ ). Também a Lei do Mandado de Segurança dilata-a, conquanto a mantenha muito vinculada ao cunho privatístico, quando autoriza a impetração da medida, "a favor do direito originário", pelo "titular de direito líquido e certo, decorrente em condições idênticas, de terceiro. se o seu titular não o fizer, em prazo razoável, apesar de para isso notificado judicialmente" (artigo $3 .^{\circ}$ ).

O Estatuto da Ordem dos Advogados do Brasil (Lei n. ${ }^{\circ} 4.215$, de 27 de abril de 1963) incursiona por esse campo, ao dizer que "cabe à Ordem representar, em juízo e fora dele, os interesses gerais da classe dos advogados e os individuais, relacionados com o exercício da profissão" (artigo 1., par. único), e que "os presidentes do Conselho Federal, da Seção e Subseção têm qualidade para agir, mesmo criminalmente, contra qualquer pessoa que infringir as disposições desta lei, e, em geral, em todos cs casos que digam respeito às prerrogativas, à dignidade e ao prestígio da advocacia", e que "podem eles intervir ainda, como assistente, nos processos-crime em que sejam acusados ou ofendidos os inscritos na Ordem" (artigo $129 \mathrm{e}$ $\left.\S 1 .{ }^{\circ}\right)$.

O mesmo sucedeu ccrm relação à Lei $n .^{\circ} 1.134$, de 14 de junho de 1950 , cujo art. $1 .^{\circ}$ dispõe que "as associações de classes existentes na dała da publicação desta lei, sem nenhum caráter político, fundadas nos termos do Código Civil e enquadradas nos dispositivos constitucionais, que congreguem funcionários ou empregados de empresas industriais da União, administradas ou não por elas, dos Estados, dos Municípios e de entidades autárquicas, de modo geral, é facultada a representação coletiva ou individual de seus associados, perante as autoridades administrativas e a justiça ordinária".

Tais determinações, conquanto representam marcante evolução, ainda parecem insuficientes, pois não afastam por inteiro o risco de o titular da pretensão ver-se na contingência de deixar de exercê-la em juízo, seja por temor de conseqüências, seja pelo custo do processo.

Lei como a de n. 1.134 teria real utilidade sob esse aspecto, se não restringisse seu âmbito às associações de servidores, cujos interesses primordiais normalmente ccstumam circunscrever-se a questões salariais. Se suas disposições fossem estendidas à tutela de quaisquer direitos e se se alargasse a permissão a quaisquer associações - mesmo instituindo, em contrapartida, multa para os abusos, como ocorre na Alemanha em relação ao recurso constitucional, de que se falará adiante - resultaria muito mais eficaz, sem dúvida, a proteção dos direitos individuais através do exercício da ação, do que sucede, hoje, com a predominante limitação da legitimidade para agir à pró.

pria

mo

cole

"pul

com

vil,

com

som

sinc

ciár

ral c

pro.

Da

§ 1.

nori

na

a a.

tem

a st

$\exp$

sivč

veli

emp

$\tan$

no.

por

Sup

Jus

Pro

o q

rep

poc 
pria pessoa atingida. Tal experiência é preconizada de há muito, como informa Trocker, que aponta a opinião de Kisch sobre as "ações coletivas" ou "ações de grupo", e bem assim as "class actions" ou "public actions", do direito norte-americano. ( $\left.{ }^{32}\right)$

Ademais, seria proveitoso que, em certos casos, fosse admitida com mais largueza a substituição processual (Código de Processo Civil, artigo $\left.6 .^{\circ}\right)$, para que as entidades acima referidas pudessem atuar com maior desembaraço e eficácia. $\left({ }^{33}\right)$

Essa dilatação da legitimidade para agir ganhou maior relevo somente perante o Direito do Trabalho, cuja legislação atribui aos sindicatos "representar, perante as autoridades administrativas e judiciárias, os interesses gerais da respectiva categoria ou profissão liberal ou os interesses individuais dos associados relatives à atividade ou profissão exercida" (Consolidação das Leis do Trabalho, artigo 513, a). Da regra geral encontram-se aplicações específicas nos artigos 791, $\S 1 .^{\circ}, 839, a, 843, \S 2 .^{\circ}, 857,869$, a e b, 872 ,parágrafo único, e 874, normas essas que facultam a associações sindicais estar em juízo na defesa de interesses gerais ou pessoais de seus filiados, de modo a afastar o risco de o interessado sofrer pressões ou represálias, ou temer sofrê-las, e, por isso, não exercer seu direito de ação. Também a substituição processual pode ser admitida em certos casos. ( $\left.{ }^{34}\right)$

17. Embora desviando um pouco o fio do raciocínio até aqui exposto, forçoso é convir que a própria norma constitucional permissiva da ação popular, facultandc-a apenas ao "cidadão", também revela acanhamento ante o que poderia proporcionar se admitido seu emprego por associações, pessoas jurídicas, partidos políticos. Limitando-a, pequeno é o proveito usufruído pelo próprio Poder Público, no controle dos atos praticados por seus servidores.

Igualmente criticável é a restrição ao emprego da representação por inconstitucionalidade, prevista na Constituição. Federal, perante o Supremo Tribunal Federal (artigo 119, 1, I), e perante os Tribunais de Justiça (artigo 15, $\S 3 .^{\circ}$, d). Ficando atribuída exclusivamente aos Procuradores-Gerais, que são integrantes da equipe do Governo, com o qual estão comprometidos (podem ser demitidos ad nutum e sofrer represálias futuras se ousarem divergir), a orientação do governo poderá comprometer a eficácia da norma.

32 "Processo Civile e Costituzione". ob. cit., pág. 10, nota n.0 15; pág. 221, nota n.0 114, págs. 222, 437 e 446. VIGORITI, "Garanzie Costitucionali del Processo Civile", Milão, 1973, págs. 15/16. V. MICHELE TARUFFO, "I Limiti Soggettivi del Giudicafo e le 'Clas Actions'", in "Rivista di Diritto Processuale, 1969, XXIV/609.

33 TROCKER, ob. cit., págs. 200 e segs.

34 COQUEIJO COSTA, "Princípios de Direito Processual do Trabalho", 1976, n.० 60, pág. 53. 
18. Verdadeiramente útil e válida seria solução como a alemã, que, através da Verfassungsbeschwerde (recurso constitucional), criada por lei ordinária de 12 de maio de 1951, depois alçada a texto constitucional (29 de janeiro de 1969), é assim descrita por Trocker: "o instituto em exame consiste em um recurso que "qualquer um" cidadão ou não cidadão, pessoa física ou pessoa jurídica, grupo ou associação de fato - pode apresentar diretamente à Corte Constitucional Federal por violação de seus direitos fundamentais (Grundrech. re) e de outras situações subjetivas ativas a estes equiparadas - entre as quais convém recordar em particular a garantia processual da de. fesa e do juiz natural - por ato de qualquer órgão do poder público. São impugnáveis tanto os atos quanto as omissões dos órgãos legislativos, executivos e judiciários. O recurso, sem custas, e que em regra pode ser apresentado diretamente pelo interessado sem necessidade de assistência técnica por um defensor, tem caráter subsidiário, ou seja, é subordinado ao emprego tempestivo e à exaustão dos meios ordinários de impugnação previstos e regulados pelo ordenamento jurídico, sempre que a questão não se revista de "importância geral" ou que ao sujeito atingido não resulte "dano grave e irreparável", oriundo do prévio exaurimento das vias de recurso ordinárias". $\left({ }^{35}\right)$

19. Mas de pouco adiantará assegurar o exercício teórico do direito de ação, ou estudar-lhe doutrinariamente a extensão e a eficácia, se o ordenamento jurídico não proporcionar meios hábeis à obtenção da sentença em tempo razoável. Manter os litigantes à espera da sentença por mil e uma noites - forma indireta de lhes denegar justiça.

Por isso mesmo a universal lentidão da marcha dos processos tem preocupado a todos quantos se ocupam do tema.

Há dois exemplos modernos de como é possível fazer muito com pouco esforço, desde que haja o desejo de por em prática medidas capazes de atender a esse reclamo.

Um deles ocorreu nos Estados Unidos da América do Norte, no início da década de 30 , gerando o que se tornou conhecido como "pre trial conference", ou seja, uma audiência preliminar em que o juiz debate com os advogados das partes, visando a limitar a matéria da audiência propriamente dita (no Brasil seria a audiência de instrução e julgamento), de modo a simplificá-la. $\left({ }^{36}\right)$

35 "Processo Civile e Constituzione", ob. cit., págs. 148/150.

36 V. entre outros: CÂNDIDO NEVES, "Impulso Processual e Poderes do Juiz", Belo Horizonte, 1949, págs. 192 e segs.; "Páginas Processuais", Belo Horizonte, 1950, págs. 119 • segs. e 148 e segs.; GALENO LACERDA, "Despacho Saneador", Porto Alegre, 1953, págs. 
Outro, ocorrido na Alemanha, é conhecido como o "modelo de Stuttgart", caracterizando-se, igualmente, por uma tentativa de simplificação capaz de permitir que o processo chegue mais rapidamente ao seu final, para o que se procura dar-lhe uma base inicial escrita mais breve, a fim de levá-lo prontamente à audiência. ${ }^{\left({ }^{37}\right)}$

Ambas as experiências têm um significativo ponto de contacto: nasceram da preocupação de alguns magistrados, sensibilizados com a demora do andamento dos processos confiados à sua direção, o que confirma a tese de René Morel, de ser "inútil ter boas leis de processo se se tem uma má organização judiciária ou juízes insuficientes, enquanto juízes de largo conhecimento jurídico podem acomodar-se a um processo medíocre". ( $\left.{ }^{38}\right)$

20. O direito luso-brasileiro não tem muito o que aprender nesse setor com legislações estrangeiras, antes podendo fornecer-lhes alguns exemplos marcantes do cuidado com que procura encarar a abreviação do desfecho dos pleitos judiciais.

Desde as Ordenações Filipinas, (L. III, T. XX, § 16) já se encontrava disposição autorizando o juiz, provocado pelo réu em defesa preliminar, a antecipar o julgamento para o fim expresso de apreciar se o autor era, mesmo, titular do direito de ação, julgando-o carecedor dela se fosse o caso, com o que evitava que o processo chegasse ao término sem possibilidade de ensejar solução do mérito da causa.

Neste século, através do despacho saneador e da extinção do processo, bem como do julgamento antecipado da lide, Portugal e Brasil são vanguardeiros na matéria.

A base escrita no processo civil brasileiro é célebre. Tanto o Código de 1939 (artigo 293), quando e atual (artigo 323), prevêm que, vencido o prazo para a defesa, o juiz seja chamado a sanear. Duas únicas peças, portanto, são essenciais no comum dos casos: petição inicial e contestação. Praxe contra a lei, contudo, introduziu a "fala sobre a contestação" - só calbível, em termos de réplica, nos casos indicados na própria lei (artigos 294, II, do Código anterior; 326 e

49 - segs.; JONATAS MILHOMENS, "Teoria - Prática do Despacho Saneador", Rio, 1958, págs. 20 e segs.; VIGORITI, "Garanzie Costiłuzionali", ob. cit., pág. 82, nota n.0 20, e - bibliografia por eles indicada. O instituto foi adotado na Dinamarca a tífulo de experiência, como informam ELISABETH THUESEN e OLE LANDO (v. "Fundamental Guarantees", ob. cit., p6́g. 352).

37 WOLFGANG GRUNSKY, "Il Cosidetto 'Modello dl Stocarda' - l'Acceleramento del Processo Civile Tedesso", In "Rivista de Diritto Processuale", 1971, XXVI/354, TROCKER, ob. cit., pág. 88.

"Traił- Elómentaire de Procédure Civile", 2." ed., Paris, 1948, pág. 3. 
327 do atual), mas tornada rotina - ao lado da "especificação de provas" - igualmente admissível em casos especiais, apenas: Código atual, artigo 324 .

A verdadeira razão de demora, mesmo, resulta de a audiência de instrução e julgamento ser designada com longos intervalos. No entanto, se occrrer circunstância que provoque imediato encerramento do processo, nem essa demora (a da audiência) se verificará.

Mas se isso pode ser dito da atuação do legislador, o mesmo, infelizmente, não é possível falar de advogados e juízes, que não costumam contribuir com soluções capazes de ombrear com as dos magistrados de Detroit e Stuttgart.

21. Esse problema, por sua vez, traz à tona outro, para o qual nem legisladores nem juízes ou tribunais dão a atenção que merece: o da falta de estatística judiciária, que possa orientar análise séria do assunto. Até hoje não se pôde chegar a apurar se, realmente, há acumulo de serviço e insuficiência de juízes e tribunais, ou falta de empenho no estudo e na preparação dos processos, que, na segunda instância, às vezes passam anos à espera de solução.

Por estas e outras razões faz-se necessário adotar medidas capazes de acelerar 0 andamento dos processos judiciais, e bem assim aprimorar a estrutura funcional do Poder Judiciário, pena de a demora imposta às partes comprometer a própria distribuição da justiça, acarretando a conseqüência de assim ser ela indiretamente denegada. (Não se esqueça a deliberação do Supremo Tribunal de mandar arquivar processos paralisados há mais de dez anos, porque ainda não tinham sido julgados).

Essas medidas, porém, não devem ser tomadas empiricamente, ao sabor de inclinações momentâneas, tampouco com idéias recolhidas unicamente entre magistrados, que só enxergam o problema do ângulo em que se encontram situados, mas em funçãol da análise de dados estatísticos capazes de permitir o equacionamento correto da questão.

2. Contudo, nada adiantará que, em teoria, o direito de ação esteja assegurado a todos e os processos se desenvolvam até mesmo com rapidez, se disso não se puderem valer efetivamente todos os interessados, Sob esse ângulo avulta o problema da participação de técnicos na condução do processo. Desde que essa é uma exigência indeclinável de sua realização, pois não está ao alcance de leigos 
conduzi-lo $\left({ }^{39}\right)$, forçoso é convir que a assistência desses especialistas - os advogados - não pcde ser privilégio: ná de estar à disposição de todos quantos deles necessitem.

E die tal forma relevante a assistência prestada por advogados, que as velhas Ordenações portuguesas, prevendo a hipótese de o litigante poderoso querer impedir seu antagonista de enfrentá-lo em pé de igualdade, continham exta dispcsição, de elevado sentido ético: "Mandamos, que se dois procuradores mais avantajados forem na Corte, e uma parte tomar ambos, não Ihe seja consentido, mas escolha um deles e deixe o outro a seu adversário, se o quiser, o qual será constrangido a procurar por ele, posto que da outra parte tenha sabido os segredos da causa, e recebido algum salário; e tornará à parte que o tinha tomado, o dinheiro, que dela tinha recebido. $E$ isto se fará geralmente me todos os feitos, de qualquer substância que sejam, para que as partes não percam seu direito por desigualdade dos procuradores" (L. III, T. XX, § 14).

23. Sendo, como é, tamanha a importância da participação do advogado, é indispensável que o Estado assegure aos que não podem pagar-ihe os honcrários a assistência judiciária prometida no artigo 153, § 32, da Constituição, como garantia individual. Se ninguém a prestar, ou se somente o fizerem alguns advogados iniciantes, em verdadeiro aprendizado complementar à custa do direito do necessitado, este ficará em óbvia inferioridade, ccm evidente lesão ao princípio da igualdade perante a lei, pois não é constitucionalmente válido deixar-lhe uma assistência judciária meramente formal, mas não substancialmente eficaz.

24. Por outro lado, se é certo que os necessitados não podem ficar desamparados, é também certo que essa assistência não podẽ ser exigida aos advcgados gratuitamente, como simples dever ine rente ao exercício da profissão, pois é nesta que têm eles a fonte de rendimentos que seu trabalho pode proporcionar. Logo, exercen-

39 Nada obstante, a legislação trabalhista alemã pró́be a participação de advogados em causas de valcr inferi:r a 300 marcos à não ser que o Presidente do Tribunal julgue-a necessária, disposição reputada válide pela Comissão Européia dos Direitos do Homem (v. JACQUES VELU, in "Fundamental Cuarantees", ob. cit., pág. 310). Nos Estad:s Unidos da América do Norte, informa SMIT, nenhum litigante, em pleito civil, necessita do intermédio de advogado para representá-lo, podendo, se quir, atuar em causa própria, muito embora norma'mente constitua advogado que o representante ("Fundamental Guarantees", cb. cit., pág. 452). Mais original ainda é a situação reinante no Japão, onde, além de o intermédio do advogado não ser necessário, "em um terço de todos os litígios civis nenhuma das partes é representada por advogedo, em outro terçs, apenas uma parte, normalmente o autor, o é, e scmente no terço restante é que ambas as partes têm advcgado" (TANIGUCHI, "Fundamental Guarantees", ob. cit., pág. 592). Diz o autor que o fato talvez decsrra da tradição, ainda viva na Asia, pois "na sociedade tradicional, antes de 1860, a profissão de advcgado foi suprimida por ser perniciosa à sociedade" (pág. 592). 
do atuação gratuita, ficam privados de remuneração, o que Ihes compromete a própria subsistência (sem falar em despesas inevitáveis para atender o próprio caso grátis).

Urge que se encontre fórmula capaz de remunerá-los, mas sem - concomitante risco da socialização da advocacia $\left({ }^{40}\right)$, que bem pode vir a resultar de se deixar a solução inteiramente a cargo do Poder Público, pois, subordinada ao Estado, a advocacia perde sua indispensável autonomia, que deve manter em face do Governo.

Seria uma farsa deixar sem assistência judiciária os que dela necessitam para poder exercer o direito de ação, do qual ficariam tolhidos; mas também constitui urna farsa impor ao advogado que a preste gratuitamente, o que expõe o necessitado, ademais, ao risco de não a ter da qualidade necessária para a complexidade do caso ou em vista do poder do adversário.

25. O direito de ação, todavia, não fica comprometido apenas quando a parte, desprovida de meios, não pode contratar advogado que a assista. Outro aspecto, não menos angustiante, se apresenta aos olhos do observador: o advogado despreparado, ainda que bem remunerado por quem o constitui, põe a perder a causa do cliente e assim impede, a prática, a prEpria realização do direito. ${ }^{(41)}$

Se o Estado criou a exclusividade do exercício da advocacia em favor dos bacharéis em direito inscritos na Ordem, há de, em contrapartida, proteger os que deles têm de valer-se contra os próprios profissionais, velando por que estejam realmente à altura de desempenhar a missão. Do contrário haverá um fosso cada vez maior entre - Direito e a realidade, entre esta e a justiça, pois sem o intermédio de advogado apto dificilmente o magistrado logrará realizar o Direito pela Sentença.

Ora, não é possível aceitar que o Estado assegure a determinadas pessoas o exercício de cerła profissão, cujo desempenho é essencial até mesmo à atuação de um dos poderes em que assenta a pró-

40 Na Inglaterra foi criado um fundo para assistência judiciária ("Legal Aid Fund"), um de cujos méritos, segundo o Prof. JOLOWICZ, é o de que "esse método de assistir ao indigente... sem chegar ao exfremo de nacionalizar as profissöes jurídicas os mesmo amea. çar-lhes a independência através de controle governamental direto, habilita os membros mais pobres da sociedade a obter assistência judiciária quase com a mesma escolha posta ao alcance dos que podem pagá-la" (original sem grifos)("Fundamental Guarantees"), ob. cit., pág. 154). A preocupação manifestada no texto, quanto à socialização da advocacia, tem, pois, sua razão de ser. Outra fórmula, p-rém, inviável no estágio atual do desenvolvimento brasileiro, seria o seguro, existente na Suécia e Dinamarca (THUESEN \& LANDO, "Fundamental Guarantees", ob. cit., págs. 344 e segs.).

41 Nos Estados Unidos da América do Norte, os tribunsis têm considerado que a garantia de defesa em processo criminal "implica no direito a um defensor competente e atuante", tese que SMIT julga aplicável também acs litígios ivis ("Fundamental Guarantees", ob. it. pág. 457). V. tamioém COMOGLIO, "La Garanziâ", ob. cił., pág. 245. 
pria Soberania e não se preocupe, paralelamente, com a qualidade intelectual dos que se preparam para esse exercício profissional. 0 problema é grave, pois não é admissível que o Direito possa ter duas (ou mais) versões, como sucede com certos idiomas, que para a plebe e para a elite são diferentes.

26. Por isso mesmo, há duas medidas, no mínimo, a serem reclamadas de imediato em nome da própria garantia constitucional do direito de ação: uma, a fiscalização da qualidade dos cursos jurídicos, cujo padrão cai a olhos vistos dia-a-dia, desservindo à Nação quem tenta obscurecer essa verdade, às vezes para assegurar posições pessoais, ou regalias; outra, umbilicamente ligada à anterior, restringir à própria Ordem dos Advogados a habilitação intelectual complementar para o exercício da profissão, através do chamado "exame de ordem", ou de cursos de estágio, talvez até com fiscalização externa, como é feito salutarmente no concurso de ingresso à carreira da Magistratura. Admitir a formação concorrente nas próprias escolas de graduação universitária, algumas das quais também se preocupam com o aspecto mercantil de sua atuação, é confessar o intuito de não solucionar problema algum.

27. Incomparavelmente mais grave é o que, sob esse mesmo aspecto, sucede com a Magistratura (e também o Ministério Público). Seus membros recebem a mesma preparação insuficiente que aflige os bacharéis em geral. Aprovados em concurso, nos quais muitas vezes há preocupação em preencher vagas para solucionar o problema burocrático dos juizados acéfalos, ingressam, vitaliciamente, numa carreira da qual é muito difícil virem a ser afastados, máximo por deficiência intelectual.

Se é angustiante o panorama com que depara o observador da classe dos advogados - que apenas postulam - é lamentável por todos os títulos vê-lo também retratado em alguns setores da Magistratura - que diz o Direito. Se é amarga a verdade de ser a constituição (o Direito, por conseqüência), o que os juízes dizem que ela é, sem dúvida a falha formação intelectual se agiganta relativamente aos magistrados.

Não se trała, é certo, de mal nacional, mas universal, que países em fase de acentuado crescimento enfrentam mais agudamente, podendo ser lembrada a dura crítica de Vittorio Colesanti, professor em Turim: "la pur galoppante svalutazione della lira è ancor poca cosa a fronte di quela della giurisprudenza". $\left({ }^{42}\right)$

42 "A desvalorização galopante da lira é ainda pouca coisa face àquela da jurisprudência" ("Rivista di Diritto Processuale", 1977, XXX11/311). Em crítica deveras rigorosa, escreve TROCKER: "se se passar, pirém, a examinar de que modo os magistrados se preparam. 
28. Já preccnizada $\left({ }^{43}\right)$, é indispensável insistir na necessidade irrefutável de criar escolas de formação de magistrados, em vista de os cursos universitários, mesmo funcionando a contento, atenderem à formação de "bacharéis", mas não de "magistrados" e a majestade da função destes, sua relevância para a segurança do Direito e, reflexamente, da própria Nação, não pode sofrer corrosão igual à que vem afetando a moeda, corrosão que está comprometendo a formação do bacharel e, ao fim e ao cabo, o próprio Direito.

Medida acertada é a instituição de cursos de formação e aperfeiçoamento de juízes, em nível de norma constitucional $\left({ }^{44}\right)$, que deve ser estendida a todos os ramos e graus. Oxalá não se convertam em mera formalidade de os Estados criarem empregos, ao invés de contribuirem para restaurar a abalada saúde de alguns setores da magistratura brasileira.

$\mathrm{Na}$ Espanha, "os candidatos aprovados desenvolvem, na Escola Judicial, criada por Lei de 18 de dezembro de 1956, três cursos semestrais, com a duração máxima de dois anos, recebendo ensinamentos de caráter teórico e prático, dadcs por um professorado selecionado entre catedráticos universitários e membros da própria carreira judicial" $\left({ }^{45}\right)$. Na França, "os magistrados são recrutados através de concurso e em seguida recebem, na Escola Nacional da Magistratura, uma formação, que se estende por vinte e oitc meses e compreende dois príodos: um, consagrado a estágios; outro, reservado ao aprendizado de matérias jurídicas, econômicas e sociais" $\left.{ }^{46}\right)$. Por

na prática, para desenvolver essa delicada tarefa, tem-se quadro não muito encorajador. Em particular, pode-se observar que os magistrados muitas vezes nem se preocupam de manter-se informados sobre os prcblemas que estão sendo agitados na ssciedade em que atuam, mas não (logram ou não) se preocupam tambám om acompanhar atentamente a elaboração do direito em nível jurisprudencial e doutrinário" (ob. cit., pág. 644, n.o 8). O jurista italiano indica vários autores alemães cujas opiniões convergem para a sua tese.

43 V.E. D. MONIZ DE ARAGÃO, "Estudo sobre os Embargos de Nulidada e Infringentes do Julgado Previstos no Código de Prucesso Civil", Curitiba, 1959, pág. 115; "Formação e Aperfsiçoamento de Juízes", in "Revista da Faculdade de Direito da Universidade do do Paraná", 1960, VII/14; EDGARD DE MOURA BITTENCOURT, "Recrutamento de Juízes e a Preparação das Profissões Judiciárias", in "Revista dos Tribunsis", 315/107.

44 Constituição Federal, artigo 144, inciso 1: "o ingresso na magistratura de carreira dar-se-á mediante concurso público de provas e títulos, realizado pelo Tribunal de Justiça, com a participsção do Conselho Secional da Ordem dos Advogados do Brasil, podendo a lei exigir dos candidatos prova de habilitação em curso de preparação para a magistrałura; a indicação dos candidat:s far-se-á sempre que possível em lista tríplice".

45 ABELARDO ALGORA MARCO, "La Carrera Judicial en España", in "Primer Congreso Mexicano y Segundas Jornadas Latinoamericanas do Derecho Procesal", México, 1960. A especialização dos juízes foi solucionada na Súça de modo singular: pessoas que não integram a magistratura, p:dem ser convccadas "a colaborar em um caso especial, tendo em conta seus conhecimentos especiais no assunto objeto do litígio; esses juízes são eleitos previamente, mas só entram em atividade se a causa incide no domínio de sua especialidade" (ALOIS TROLLER, "Fundemental Guzrantees", cb. cit., pág. 631). BRUNO OPPET|T, "Fundamental Guarantees", cb. cił., pág. 494. 
evidente influência francesa, o Senegal envia seus candidatos a juiz a cursar a Esccla Nacional da Magistratura da França, por um período de dezoito meses. $\left({ }^{47}\right)$

29. A primeira afirmativa a ser feita, antes mesmo de iniciar as conclusões, é esta: urge restaurar o Estado de Direito, sem o que as considerações acima expostas não terão maior significado. $\left.{ }^{48}\right)$ Por melhores que sejam, juízes sem garantias não oferecem aos litigantes segurança da obtenção, junto ao Poder Judiciário, da proteção inscrita no preceito constitucional do artigo $158, \S 4 .^{\circ}$. Se essas garantias fossem despiciendas, nenhuma carta constitucional, nenhum doutrinador, Ihes dedicarão atenção.

Passando às conclusões, afirma-se que:

a) em Estado de Direito é inaceitável qualquer restrição de natureza meramente política ao exercício do direito de ação, cuja possibilidade jurídica não deve ficar à mercê de normas como a do artigo 319, do Código de Processo Civil de 1939, ou como as que, presentemente, subtraem à apreciação do Poder Judiciário a lesão de direitos individuais, desde que praticada à sombra dos chamados "atos Institucionais'.

b) é recomendável que se processe uma revisão do conceito de legitimidade para agir, a fim de lhe dar maior elasticidade, de modo a que o direito de ação, em se tratando de proteger garantias constitucionais, não fique exposto ao risco de o interessado não poder exercê-lo, cedendo a pressões, por falta de meios, ou temor de represálias;

c) em consequiência, são criticáveis restrições como as dos artigos 153, § 31; 119, inc. l, al./, e 15, § 3. ${ }^{\circ}$, al. d, da Constituição Federal, que circunscrevem a legitimidade para o exercício da ação popular e da argüição de inconsticionalidade. Conv-m que essas medidas sejam facultadas também a pessoas jurídicas, para que possam exercê-las por outrem, semelhantemente ao que sucede na Alemanha com a Verfassungsbeschwerde, cuja adoção no Brasil é recomendada;

d) é inadiável a instituição de estatísticas judiciárias, que forneçam dados realmente hábeis à reformulação de estrutura do Poder Judiciário em todos os níveis, a fim de, com isso, além de afastar o empirismo, dinamizar em base científica o seu funcionamento;

47 KEEBA M'BAYE, "Fundamental Guarantees", ob. cił., pág. 603.

48 Bem observou ○ Prof. JOLOWICZ que "a independência dos juízes face à interferência estatal depende de salvaguardas políticas, não apenas legais" ("Fundamental Guarantees", ob. cit., pág. 134). 
e) para que a garantia do direito de ação seja eficaz, é indispensável que seja prestada assistência judiciária aos necessitados. Mas o ônus não deve recair apenas sobre os advogados nomeados para esse fim em casos específicos;

f) é necessário que seja exercida severa fiscalização sobre os cursos jurídicos, cujo padrão de qualidade tem caído a olhos vistos, para que a deficiência da formação dos bacharéis em direito não venha a acarretar danos à própria realização do Direito pelo processo judicial;

g) é necessário serem criadas escolas de formação de magistrados, a que alude a norma constitucional, mas impõe-se não apenas abranger na medida todos os ramos do Poder Judiciário, como o posterior aprimoramento dos juízes que o integram. 